PREPARED FOR THE U.S. DEPARTMENT OF ENERGY, UNDER CONTRACT DE-AC02-76CH03073

PPPL-3761

PPPL-3761

UC-70

Next Step Spherical Torus Design Studies

by

C. Neumeyer, P. Heitzenroeder, C. Kessel, M. Ono,

M. Peng, J. Schmidt, R. Woolley, and I. Zatz

November 2002

N/W

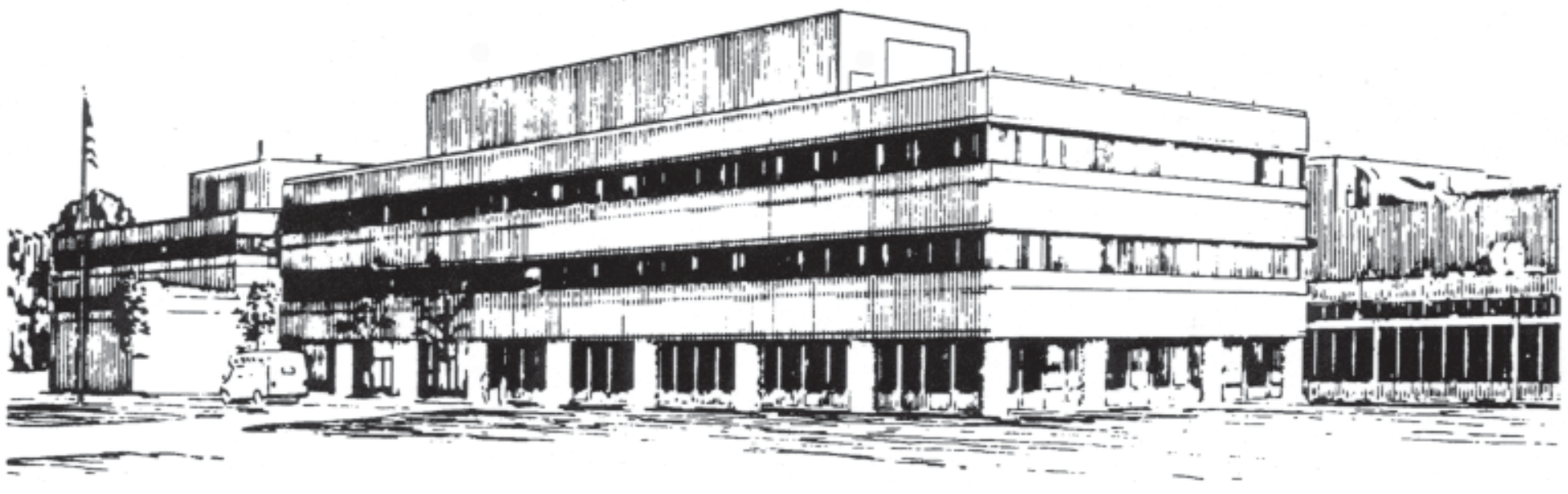

PRINCETON PLASMA PHYSICS LABORATORY PRINCETON UNIVERSITY, PRINCETON, NEW JERSEY 


\section{PPPL Reports Disclaimer}

This report was prepared as an account of work sponsored by an agency of the United States Government. Neither the United States Government nor any agency thereof, nor any of their employees, makes any warranty, express or implied, or assumes any legal liability or responsibility for the accuracy, completeness, or usefulness of any information, apparatus, product, or process disclosed, or represents that its use would not infringe privately owned rights. Reference herein to any specific commercial product, process, or service by trade name, trademark, manufacturer, or otherwise, does not necessarily constitute or imply its endorsement, recommendation, or favoring by the United States Government or any agency thereof. The views and opinions of authors expressed herein do not necessarily state or reflect those of the United States Government or any agency thereof.

\section{Availability}

This report is posted on the U.S. Department of Energy's Princeton Plasma Physics Laboratory Publications and Reports web site in Fiscal Year 2003. The home page for PPPL Reports and Publications is: http://www.pppl.gov/pub_report/

DOE and DOE Contractors can obtain copies of this report from:

U.S. Department of Energy

Office of Scientific and Technical Information

DOE Technical Information Services (DTIS)

P.O. Box 62

Oak Ridge, TN 37831

Telephone: (865) 576-8401

Fax: (865) 576-5728

Email: reports@adonis.osti.gov

This report is available to the general public from:

National Technical Information Service

U.S. Department of Commerce

5285 Port Royal Road

Springfield, VA 22161

Telephone: $1-800-553-6847$ or

(703) $605-6000$

Fax: (703) 321-8547

Internet: http://www.ntis.gov/ordering.htm 


\title{
Next Step Spherical Torus Design Studies ${ }^{\dagger}$
}

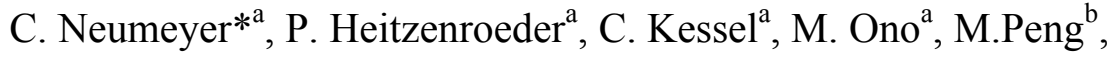 \\ J. Schmidt ${ }^{\mathrm{a}}$, R. Woolley ${ }^{\mathrm{a}}, \mathrm{I}_{\text {. Zatz }}{ }^{\mathrm{a}}$ \\ ${ }^{a}$ Princeton University Plasma Physics Laboratory, P.O. Box 451, Princeton, New Jersey, USA, 08540 \\ ${ }^{b}$ Oak Ridge National Laboratory, P.O. Box 2008, Oak Ridge, Tennessee, USA, 37831 \\ $\dagger$ \\ This work is supported by USDoE Contract No. DE-AC02-76CH03073
}

\begin{abstract}
Studies are underway to identify and characterize a design point for a Next Step Spherical Torus (NSST) experiment. This would be a "Proof of Performance" device which would follow and build upon the successes of the National Spherical Torus Experiment (NSTX) "Proof of Principle" device which has operated at PPPL since 1999. With the Decontamination and Decommissioning (D\&D) of the Tokamak Fusion Test Reactor (TFTR) nearly completed, the TFTR test cell and facility will soon be available for a device such as NSST. By utilizing the TFTR test cell, NSST can be constructed for a relatively low cost on a short time scale. In addition, while furthering spherical torus (ST) research, this device could achieve modest fusion power gain for short pulse lengths, a significant step toward future large burning plasma devices now under discussion in the fusion community. The selected design point is $\mathrm{Q}=2$ at $\mathrm{HH}=1.4$, Pfusion $=60 \mathrm{MW}, 5$ second pulse, with $\mathrm{R} 0=1.5 \mathrm{~m}, \mathrm{~A}=1.6, \mathrm{Ip}=10 \mathrm{MA}, \mathrm{Bt}=2.6 \mathrm{~T}$, CS flux $=16$ weber. Most of the research would be conducted in DD, with a limited DT campaign during the last years of the program.
\end{abstract}

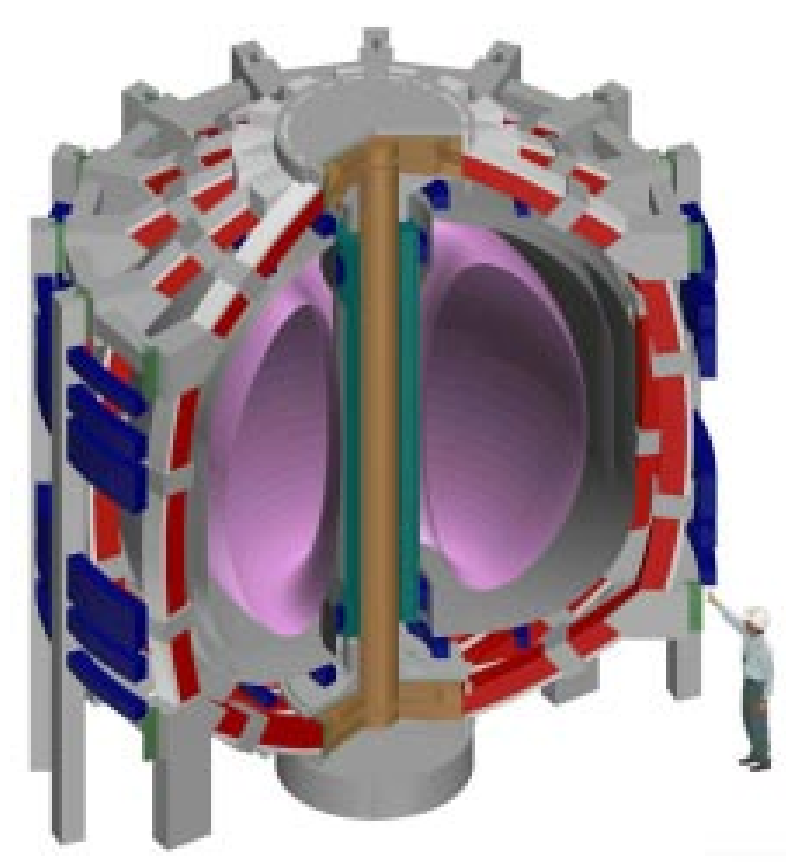

Fig. 1. Isometric View of NSST

*Corresponding author

Tel. (609) 243-2159 FAX (609) 243-2222

e-mail: neumeyer@pppl.gov

\section{Introduction}

Results obtained thus far on NSTX [1,2] with NBI heated plasmas, including $\beta_{\text {toroidal }} \sim 30 \%, \beta_{\mathrm{N}} \sim 6.0 \%$ with, simultaneously, good confinement $(\mathrm{HH} \sim 1.4)$ are very encouraging and supportive of the next step. Although several years remain before the NSTX results will be sufficient to justify proceeding with a NSST device, it is appropriate to develop a next step concept now and begin planning in order to ensure a smooth transition and also to provide focus to the NSTX Research Program.

The key issues for the ST are 1) characterization of stability limits and confinement, 2) power and particle handling, and 3) non-inductive current startup and sustainment. NSST would aim to extend the knowledge base in these areas beyond the levels achieved on NSTX to a much larger scale, approaching burning plasma conditions with significant alpha particle heating via a D-T campaign toward the end of the research program.

At the present time a conservative physics approach is warranted, but flexibility needs to be maintained in anticipation of future developments. Therefore we assume $\mathrm{HH}=1.4$ for our baseline scenarios. And an 
Ohmic Heating $(\mathrm{OH})$ solenoid, sufficient to drive the $\mathrm{Q}=2,5$ second, $\mathrm{I}_{\mathrm{p}}=10 \mathrm{MA}$ "high performance" pulse, is included in the proposed design. However, the long-term goal of NSST is to develop non-inductive start-up and sustainment. Toward this end we envision various "long pulse" (up to 50s) regimes operating at lower current and Q. One type would utilize partial swing of the $\mathrm{OH}$ for start-up, with noninductive current sustainment via Neutral Beam Injection (NBI). Another more advanced scenario would start and sustain the current using fully noninductive means, taking advantage of the long pulse length to ramp up the current.

In order to arrive at a design point for NSST, parametric studies were performed using a Systems Code [3] which includes a 0 -d analysis of the plasma along with engineering algorithms [4] which calculate the stress, temperature rise, power, and energy consumption of the Toroidal Field (TF), OH, and Poloidal Field (PF) magnets. Using this tool an optimization was performed which aimed to maximize $\mathrm{Q}$ and minimize major radius $\mathrm{R}_{0}$ with the constraint of the engineering allowables, including the available power (800MW) and energy (4.5GJ) available from the existing motor-generator (MG) system. Auxiliary heating power was limited to $30 \mathrm{MW}$, which is available via existing equipment

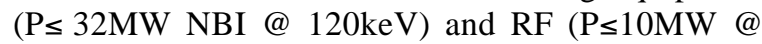
$30 \mathrm{MHz})$. The primary target of the optimization was the fully inductive $\mathrm{Q}=2$ scenario. Then, with the machine dimensions established, the long pulse capability was determined. The mission operating envelope is described in Figure 2, and the design point details in Table 1.

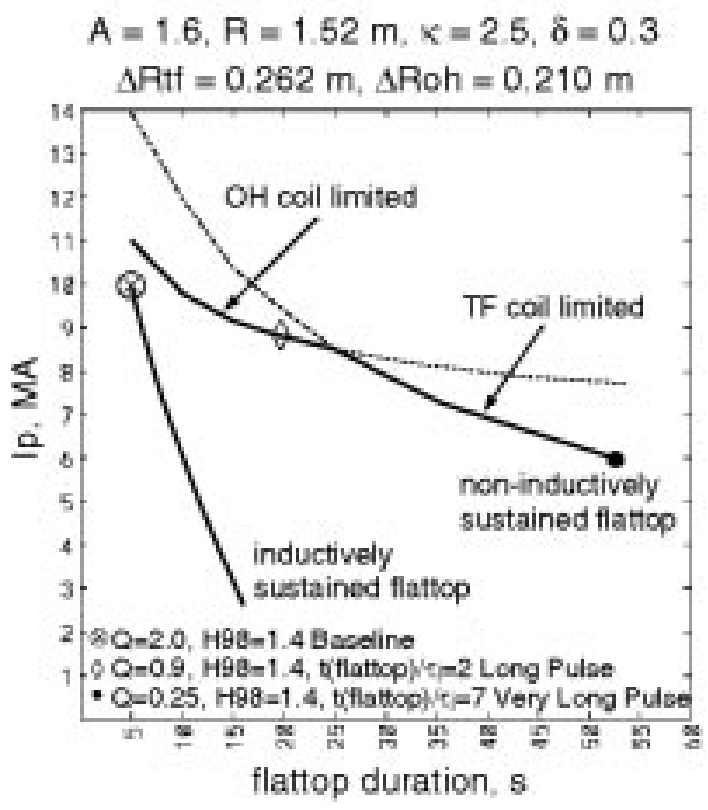

Fig. 2. NSST Operating Envelope
Table 1

NSST Design Point

\begin{tabular}{llccc}
\hline & & High & Long & \\
$\mathrm{R}_{0}$ & Major Radius & $\begin{array}{c}\text { Perf. } \\
\text { Pulse }\end{array}$ & \\
$\mathrm{A}$ & Aspect Ratio & 1.6 & 1.5125 & $\mathrm{~m}$ \\
$\mathrm{~B}_{\mathrm{t}}$ & Toroidal Field & 2.6 & 1.15 & - \\
$\mathrm{I}_{\mathrm{p}}$ & Plasma Current & 10.1 & 6.2 & $\mathrm{~T}$ \\
$\kappa$ & Elongation & 2.5 & 2.5 & - \\
$\delta$ & Triangularity & 0.3 & 0.3 & - \\
$\mathrm{q}_{\mathrm{MHD}}$ & Safety Factor & 8.2 & 6.1 & - \\
$\beta_{\mathrm{T}}$ & Beta toroidal & 13.3 & 26.3 & $\%$ \\
$\beta_{\mathrm{P}}$ & Beta poloidal & 68.2 & 74.2 & $\%$ \\
$\beta_{\mathrm{N}}$ & Beta normal & 3.2 & 4.64 & $\%$ \\
$\mathrm{P}_{\alpha}$ & Alpha power & 12.0 & 1.5 & $\mathrm{MW}$ \\
$\mathrm{P}_{\text {brems }}$ & Bremstrahlung & 6.7 & 1.4 & $\mathrm{MW}$ \\
$\mathrm{P}_{\text {fusion }}$ & Fusion power & 60.0 & 7.5 & $\mathrm{MW}$ \\
$\mathrm{P}_{\text {aux }}$ & Heat. \& CD & 30.0 & 30.0 & $\mathrm{MW}$ \\
$<\mathrm{n}_{\mathrm{e}}>$ & Density & 2.1 & 1.0 & $10^{20} / \mathrm{m} 3$ \\
$\mathrm{f}_{\mathrm{GW}}$ & Frac. Greenwald & 63.3 & 50.7 & $\%$ \\
$\left\langle\mathrm{~T}_{\mathrm{e}}>\right.$ & Temperature & 5.5 & 4.5 & $\mathrm{keV}$ \\
$\mathrm{T}_{\text {flat }}$ & Flat top time & 5.0 & 50.0 & $\mathrm{~s}$ \\
$\mathrm{HH}$ & Confinement & 1.4 & 1.4 & - \\
$\tau_{\mathrm{E}} * \mathrm{HH}$ & Confinement time & 1.0 & 0.5 & $\mathrm{~s}$ \\
$\mathrm{f}_{\mathrm{BS}}$ & Bootstrap fraction & & 36.7 & $\%$ \\
$\Phi_{\text {oh }}$ & OH flux & 15.8 & 9.0 & $\mathrm{~W}$ \\
\hline & & & & \\
\hline
\end{tabular}

\section{Device Overview}

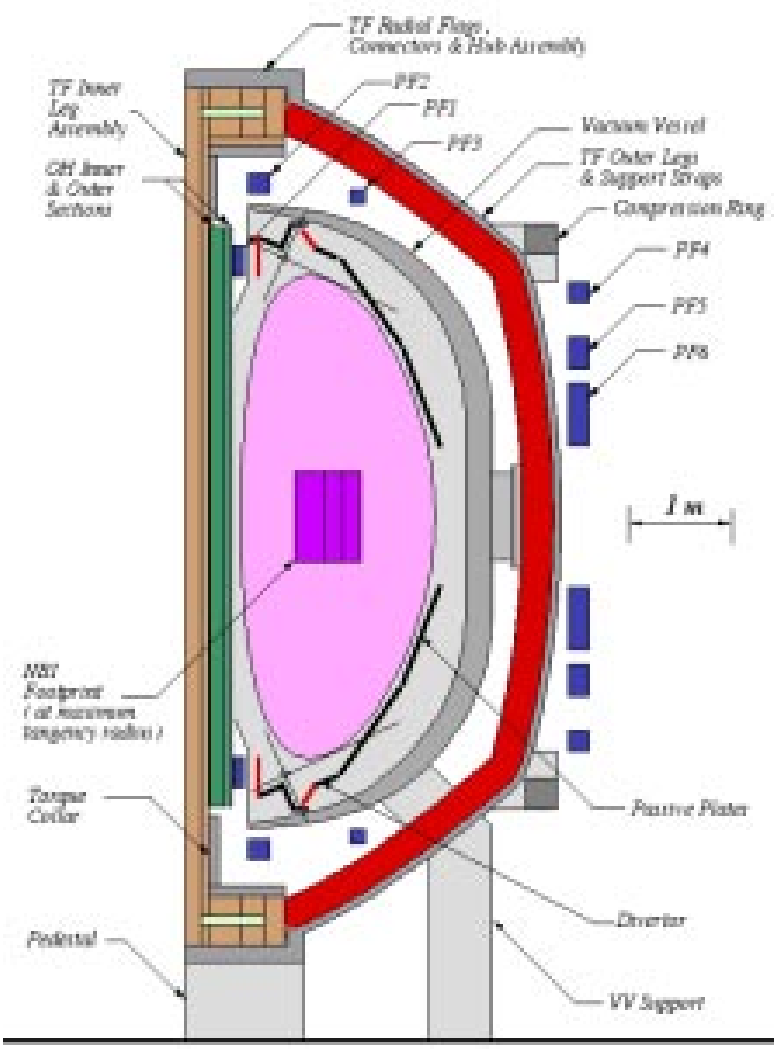

Fig. 3. NSST Cross Section 


\section{TF Coil System}
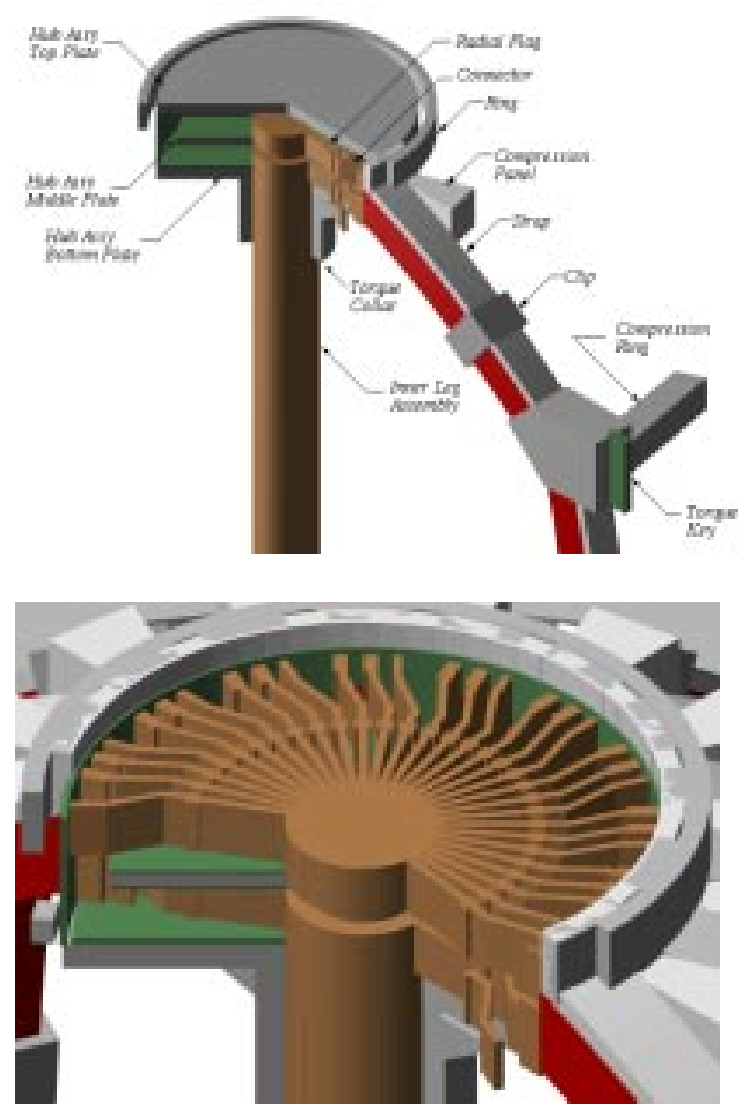

Fig. 4. NSST TF Coil Features

Like NSTX, NSST features a demountable TF coil design, which permits the "center stack" of the device (i.e. the TF Inner Legs, OH Coil Sections, PF1a coils, and the inner section of the vacuum vessel) to be removed separately as an integrated assembly. The TF inner legs, consisting of 96 standard OFHC copper $(\mathrm{Cu})$ turns of wedged shaped conductors arranged in two layers, are cooled by liquid nitrogen $\left(\mathrm{LN}_{2}\right)$ via passages extruded in the conductors. Turn cross-sectional areas are slightly different in the two layers to account for the difference in magnetoresistive effect. Turn-turn transitions in the two layers proceed in opposite directions so as to cancel the net toroidal current. The 96 turn design is selected because 1$)$ the current $(205 \mathrm{kA})$ and voltage $(2 \mathrm{kV})$ are matched to an integral number of existing PPPL Dsite AC/DC converter sections, 2) integer multiple of 16 outer legs is required to meet the TF ripple requirement ( $\leq 0.5 \%$ at $\mathrm{R}_{0}+\mathrm{a}$ on the midplane), 3 ) integer multiple of 4 is required for convenience of manufacturing in quadrants, 4) sufficient perimeter is available per turn for making bolted connection to radial flags. The assembly is fabricated in a fashion similar to NSTX, except a high temperature, high shear stress cyanate ester resin system is used. Torsional loads arising from the $\mathrm{OH}$ radial field crossing the TF current are reacted through the outer TF coil legs and structures via torque collars clamped around the inner leg assembly at the ends of the $\mathrm{OH}$ coil. The torque collars attach to the hub which, in turn, is attached to the outer TF coil legs and structures. The current density in the outer legs is relatively low and the temperature rise is less than $10^{\circ} \mathrm{C}$ per pulse. They are cooled by the exit flow of nitrogen (gas initially; liquid at full cool-down) routed though extruded passages in the outer leg conductor. Radial flags and connectors are used to make the joints between the inner legs and the outer legs. The radial flags are wedged into a hub assembly to form a monolithic structure. The connectors are slightly flexible in the radial direction to avoid the development of a large radial force on the flags, and to allow the outer legs to rest against their support structure.

The shape of the outer legs is chosen such that the outward magnetic pressure due to the TF current crossing with the TF field results in a constant tension in the support strap, with minimal vertical tension imposed on the inner legs. Compression rings are used to adjust the constant tension shape to suit the desired height of the TF coil assembly. With the constant tension, moment-free shape, the outer legs and associated support structure can be made relatively flexible in the axial direction, thereby allowing the thermal expansion and contraction of the inner leg assembly without generating large stresses.

The outer leg out-of-plane forces due to the radial component of TF current crossing with the vertical field of the PF coils are transmitted to the strap assembly via the compression panels and straps. The intrinsic torsional rigidity of the strap/compression ring structure is supplemented by mechanical keys which transmit torsional loads to the "cage" surrounding the machine which is formed by PF coil support columns and the compression rings. Shear panels between the PF support columns will be added if further analyses indicates the need for additional torsional stiffness.

\section{Ohmic Heating (OH) Coil System}

A two-part $\mathrm{OH}$ coil is used, consisting of two concentric sections, with different current density in each section to increase the total available flux. The sections are connected in series and carry the same current per turn. The outer section uses standard OFHC copper $(\mathrm{Cu})$ conductor, which is operated at its thermal limit. The inner radius of the outer section is chosen such that the hoop stress is at the allowable limit for copper. The inner section uses a beryllium copper $(\mathrm{BeCu})$ alloy operating at its thermal limit. Due to the higher strength and lower conductivity of the $\mathrm{BeCu}$, the inner layer is thermally limited but 
does not reach its allowable stress. The $\mathrm{OH}$ coil sections are cooled by $\mathrm{LN}_{2}$ flowing through the annular regions between the $\mathrm{OH}$ and $\mathrm{TF}$ coils and between the $\mathrm{OH}$ sections. The bipolar swing of $\mathrm{OH}$ current is asymmetric about zero to exploit the higher strength of the conductors at cold temperatures during the first swing, with the ratio of the first swing of current to the second swing equal to 1.8 .

\section{Poloidal Field (PF) Coil System}

The PF Coil System consists of 6 coil pairs symmetric about the device midplane. Current per turn is $24 \mathrm{kA}$ in all circuits, based on the rating of the existing power supplies. In the present design, the PF coils are wound using hollow copper conductors cooled by water. However, a large thermal gradient will exist between the PF coils and TF outer legs and associated structure, which may present some difficulties in the design of the structural features and thermal insulation. Therefore, another option under consideration is to cool the PF coils with $\mathrm{LN}_{2}$. In this case the entire device would be housed in a cryostat.

\section{Internal Hardware}

Internal hardware consists of the inboard first wall, inboard and outboard divertors, and passive plates. With respect to the Plasma Facing Components (PFCs) the philosophy of NSST is to employ beryllium and carbon-based materials during the initial phases of the program, and then upgrade to allmetallic components, including tungsten brush divertor technology, for the D-T phase. The inboard first wall consists of interlocking CFC tiles with suitable mounting system to attach to the center stack casing, passively cooled. Tile thickness is 1.25 " with an allowance of 0.25 " for mounting hardware. The primary and secondary passive plates are similar to those used in NSTX, consisting of $16+16=32$ discrete plates in each half plane. Each plate consists of 0.5 " thick copper-chromium-zirconium $(\mathrm{CuCrZr})$ backing plates, $1.0 \mathrm{~m}$ in poloidal length, formed into a conical shape, covered with 0.5 " thick $\mathrm{CuCrZr}$ tiles coated with 0.2" plasma sprayed Be armor. Plates are attached to the vessel via strong-backs mounted to cylindrical section of vessel between ports. Piping is provided for a helium system for $350^{\circ} \mathrm{C}$ bakeout.

\section{Vacuum Vessel}

A double walled vacuum vessel with integral shielding is used on NSST. The vessel is fabricated of $316 \mathrm{SS}$. The inner wall is $3 / 4$ " thick and the outer wall, which has lower stress, is, $5 / 8$ " thick. Welded ribs are provided between the inner and outer walls to stiffen the structure. The inner space between walls is filled with $60 \%$ 316SS balls and $40 \%$ water. Ports are based on 16-fold symmetry. Four (4) midplane ports are included to accommodate the TFTR NBI. Eight (8) pairs of 6" diameter ports are included to accept feed-throughs for an 8 strap RF antenna subtending $8 * 7.5^{\circ}=60^{\circ}$. The remaining nine (9) rectangular midplane ports are 24 " wide x 36 " tall. Sixteen (16) 12" diameter ports are provided on upper and lower domes. The vessel assembly is provided with connections for water heating/cooling in the inner space for $150^{\circ} \mathrm{C}$ bakeout. The inner wall of the vacuum vessel is formed by the 0.1875 " thick Inconel "center stack casing" with bellows and flanges to allow for differential thermal expansion with respect to the outer vacuum vessel.

\section{Key Engineering Feasibility Issues}

The design studies have focused on 10 key issues:

1) $\mathrm{TF}$ inner leg torque reaction and shear stress in the inner leg turn insulation;

2) TF inner leg-to-outer leg interface, allowing for axial thermal displacement of the inner legs, and vertical separating force on outer legs, without excessive tension/compression;

3) $\mathrm{TF}$ joint and connector scheme;

4) TF outer leg positioning, field ripple, NBI access;

5) $\mathrm{OH}$ coil performance optimization;

6) $\mathrm{TF}$ and $\mathrm{OH}$ coil cooling;

7) PFC heat loads and technologies;

8) Handling of center stack within the physical constraints of the existing Test Cell;

9) Neutron flux, fluence, and shielding requirements;

10) Overall power and energy match to PPPL site.

\section{Conclusions}

The key engineering feasibility issues have been addressed and resolved, at least at a conceptual level. Work will continue to further develop the physics and engineering concepts for NSST, which offers the opportunity for a cost effective experiment which can be constructed on a relatively short time scale

\section{References}

[1] D. Gates, et al, Recent Progress on the National Spherical Torus Experiment (NSTX), Controlled Fusion and Plasma Physics (Proc. 29nd Eur. Conf., Montreux, 2002) ECA Vol. 26B

[2] C. Neumeyer et al, Engineering Design of the NSTX, Fusion Engineering and Design, vol. 54, p. 275-319, 2001

[3] S. Jardin et al, Systems Analysis of a Compact Next Step Burning Plasma Experiment, PPPL3666 (2002), to appear in Fusion Engineering Design

[4] C. Neumeyer et al, Spherical Torus Center Stack Design", Proc. of $19^{\text {th }}$ Symposium on Fusion Engineering, Atlantic City, NJ, January 2002 


\section{External Distribution}

Plasma Research Laboratory, Australian National University, Australia

Professor I.R. Jones, Flinders University, Australia

Professor João Canalle, Instituto de Fisica DEQ/IF - UERJ, Brazil

Mr. Gerson O. Ludwig, Instituto Nacional de Pesquisas, Brazil

Dr. P.H. Sakanaka, Instituto Fisica, Brazil

The Librarian, Culham Laboratory, England

Library, R61, Rutherford Appleton Laboratory, England

Mrs. S.A. Hutchinson, JET Library, England

Professor M.N. Bussac, Ecole Polytechnique, France

Librarian, Max-Planck-Institut für Plasmaphysik, Germany

Jolan Moldvai, Reports Library, MTA KFKI-ATKI, Hungary

Dr. P. Kaw, Institute for Plasma Research, India

Ms. P.J. Pathak, Librarian, Insitute for Plasma Research, India

Ms. Clelia De Palo, Associazione EURATOM-ENEA, Italy

Dr. G. Grosso, Instituto di Fisica del Plasma, Italy

Librarian, Naka Fusion Research Establishment, JAERI, Japan

Library, Plasma Physics Laboratory, Kyoto University, Japan

Research Information Center, National Institute for Fusion Science, Japan

Dr. O. Mitarai, Kyushu Tokai University, Japan

Library, Academia Sinica, Institute of Plasma Physics, People's Republic of China

Shih-Tung Tsai, Institute of Physics, Chinese Academy of Sciences, People's Republic of China

Dr. S. Mirnov, TRINITI, Troitsk, Russian Federation, Russia

Dr. V.S. Strelkov, Kurchatov Institute, Russian Federation, Russia

Professor Peter Lukac, Katedra Fyziky Plazmy MFF UK, Mlynska dolina F-2, Komenskeho Univerzita, SK-842 15 Bratislava, Slovakia

Dr. G.S. Lee, Korea Basic Science Institute, South Korea

Mr. Dennis Bruggink, Fusion Library, University of Wisconsin, USA

Institute for Plasma Research, University of Maryland, USA

Librarian, Fusion Energy Division, Oak Ridge National Laboratory, USA

Librarian, Institute of Fusion Studies, University of Texas, USA

Librarian, Magnetic Fusion Program, Lawrence Livermore National Laboratory, USA

Library, General Atomics, USA

Plasma Physics Group, Fusion Energy Research Program, University of California at San Diego, USA

Plasma Physics Library, Columbia University, USA

Alkesh Punjabi, Center for Fusion Research and Training, Hampton University, USA

Dr. W.M. Stacey, Fusion Research Center, Georgia Institute of Technology, USA

Dr. John Willis, U.S. Department of Energy, Office of Fusion Energy Sciences, USA

Mr. Paul H. Wright, Indianapolis, Indiana, USA 
The Princeton Plasma Physics Laboratory is operated by Princeton University under contract with the U.S. Department of Energy.

\author{
Information Services \\ Princeton Plasma Physics Laboratory \\ P.O. Box 451 \\ Princeton, NJ 08543
}

Phone: 609-243-2750

Fax: 609-243-2751

e-mail: pppl_info@pppl.gov

Internet Address: http://www.pppl.gov 